\title{
Spectral absorption of biomass burning aerosol determined from retrieved single scattering albedo during ARCTAS
}

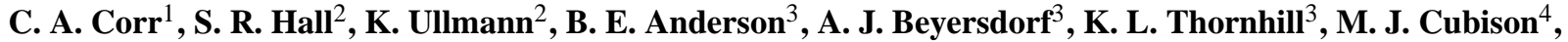 \\ J. L. Jimenez ${ }^{4}$, A. Wisthaler ${ }^{5}$, and J. E. Dibb ${ }^{1}$ \\ ${ }^{1}$ Earth Systems Research Center, University of New Hampshire, Durham, NH, 03824, USA \\ ${ }^{2}$ Atmospheric Chemistry Division, National Center for Atmospheric Research, Boulder, Colorado, 80301, USA \\ ${ }^{3}$ NASA Langley Research Center, Hampton, VA, 23681, USA \\ ${ }^{4}$ Cooperative Institute for Research in Environmental Sciences (CIRES) and Department of Chemistry and Biochemistry, \\ University of Colorado at Boulder, Boulder, CO, 80309, USA \\ ${ }^{5}$ Institute for Ion Physics and Applied Physics, University of Innsbruck, Innsbruck, Austria
}

Correspondence to: C. A. Corr (ccorr@unh.edu)

Received: 16 May 2012 - Published in Atmos. Chem. Phys. Discuss.: 5 June 2012

Revised: 8 October 2012 - Accepted: 11 October 2012 - Published: 12 November 2012

\begin{abstract}
Actinic flux, as well as aerosol chemical and optical properties, were measured aboard the NASA DC-8 aircraft during the ARCTAS (Arctic Research of the Composition of the Troposphere from Aircraft and Satellites) mission in Spring and Summer 2008. These measurements were used in a radiative transfer code to retrieve spectral (350$550 \mathrm{~nm}$ ) aerosol single scattering albedo (SSA) for biomass burning plumes encountered on 17 April and 29 June. Retrieved SSA values were subsequently used to calculate the absorption Angstrom exponent (AAE) over the 350-500 nm range. Both plumes exhibited enhanced spectral absorption with AAE values that exceeded $1(6.78 \pm 0.38$ for 17 April and $3.34 \pm 0.11$ for 29 June). This enhanced absorption was primarily due to organic aerosol (OA) which contributed significantly to total absorption at all wavelengths for both 17 April (57.7\%) and 29 June 56.2\%). OA contributions to absorption were greater at UV wavelengths than at visible wavelengths for both cases. Differences in AAE values between the two cases were attributed to differences in plume age and thus to differences in the ratio of $\mathrm{OA}$ and black carbon (BC) concentrations. However, notable differences between $\mathrm{AAE}$ values calculated for the $\mathrm{OA}\left(\mathrm{AAE}_{\mathrm{OA}}\right)$ for 17 April (11.15 \pm 0.59$)$ and 29 June $(4.94 \pm 0.19)$ suggested differences in the plume AAE values might also be due to differences in organic aerosol composition. The 17 April OA was much more oxidized than the 29 June OA as denoted by a higher oxidation state value for 17 April (+0.16 vs. -0.32).
\end{abstract}

Differences in the $\mathrm{AAE}_{\mathrm{OA}}$, as well as the overall AAE, were thus also possibly due to oxidation of biomass burning primary organic aerosol in the 17 April plume that resulted in the formation of OA with a greater spectral-dependence of absorption.

\section{Introduction}

Aerosols directly scatter and absorb visible $(400 \mathrm{~nm} \leq$ $\lambda \leq 700 \mathrm{~nm}$ ) solar radiation thereby impacting climate (e.g. Forster et al., 2007) as well as visibility (e.g. McMeeking et al., 2006). Aerosol scattering and absorption can also significantly impact ultraviolet (UV) radiation $(\lambda<400 \mathrm{~nm})$ and therefore photochemistry (Dickerson et al., 1997; He and Carmichael, 1999; Lefer et al., 2003; Flynn et al., 2010; Li et al., 2011). The relative contribution of absorption and scattering to extinction due to aerosols is largely governed by composition; while all aerosols efficiently scatter radiation of wavelengths similar to particle diameter, certain types of aerosols also strongly absorb radiation due to the presence of absorbing material in the particles. Absorbing aerosols act to warm the atmosphere, which reduces the magnitude of the global net cooling due to aerosol scattering of incoming radiation (Forster et al., 2007). Additionally, absorbing aerosols impact photochemistry differently than scattering aerosol resulting in a notably larger decrease in photochemical smog 
formation compared to dominantly scattering aerosol (e.g. He and Carmichael, 1999).

Carbonaceous aerosol, the sum of inorganic black carbon (BC) and organic aerosol (OA), represents one of the largest pools of absorbing aerosol globally. While $\mathrm{BC}$ is known to absorb strongly at all wavelengths, OA absorption is much more spectrally dependent, with greatest OA absorption at shorter $(\leq 400 \mathrm{~nm})$ wavelengths. This spectral dependence has been summarized by the absorption Angstrom exponent (AAE), the fit to an exponential relationship between the absorption coefficient $\left(b_{\mathrm{abs}, \lambda}\right)$ and wavelength (Kirchstetter et al., 2004; Lewis et al., 2008; Marley et al., 2009; Chen and Bond, 2010).

In order to truly capture the spectral dependence of OA absorption, AAE should be calculated from $b_{\mathrm{abs}, \lambda}$ that extends into the UV where OA absorption is strongest. While aerosol absorption measurements at a few discrete UV wavelengths exist, high resolution absorption measurements below $400 \mathrm{~nm}$ are lacking. Recent studies have determined aerosol absorption and the AAE from aerosol single scattering albedo (SSA) which describes the contribution of scattering $\left(b_{\text {scat }, \lambda}\right)$ to aerosol extinction $\left(b_{\text {ext }, \lambda}\right)$ (Bergstrom et al., 2007; Marley et al., 2009; Russell et al., 2010). However, measurements of SSA have been largely limited to the visible due to few scattering and absorption measurements at UV wavelengths. Recent studies have thus relied on the retrieval of UV SSA values from radiation measurements (e.g., Petters et al., 2003; Krotkov et al., 2005b; Barnard et al., 2008; Corr et al., 2009; Buchard et al., 2011). In addition to including values at UV wavelengths, SSA retrieved from radiation measurements often has a high spectral resolution making it possible to determine AAE calculations from multiple wavelength exponential fits.

Retrievals have been performed using both irradiance (the radiation incident on a plane expressed in $\mathrm{W} \mathrm{m}^{-2}$ ) as well as actinic flux (radiation to a point) (e.g., Petters et al., 2003; Krotkov et al., 2005b, 2011; Barnard et al., 2008; Corr et al., 2009; Buchard et al., 2011). Unlike irradiance, actinic flux does not account for photon direction or "source" (e.g., direct from the sun or scattered from the atmosphere and/or surface). While the absence of direction makes actinic flux suitable for quantifying photochemistry on the molecular level, it makes distinguishing diffuse flux (produced from atmospheric and surface scattering) and direct flux more difficult. This ultimately makes identifying variability due to aerosol scattering and/or absorption using actinic flux much more difficult than irradiance. As a result, irradiance has been the preferred radiation measurement in previous SSA and AAE retrievals (e.g., Petters et al., 2003; Krotkov et al., 2005b; Corr et al., 2009; Buchard et al., 2011). However, as actinic flux is used to quantify the rate of many atmospheric photochemical reactions, being able to use it in aerosol retrievals would allow for the direct determination of aerosol impacts on photochemistry.
The ability to calculate AAE values using radiation measurements suggests aerosol spectral absorption properties can be determined from remote sensing platforms. Further, as differences in the spectral absorption characteristics of aerosols are related to differences in aerosol chemistry, such AAE retrievals imply remote sensing of aerosol chemical composition should be possible. Bergstrom et al. (2007) and Russell et al. (2010) have demonstrated this by showing distinct differences in AAE values determined from SSA retrieved using irradiance for plumes dominated by different types of aerosols (e.g., urban, desert dust, biomass burning).

Presented here are AAE values calculated from SSA values retrieved using actinic flux measurements made aboard the NASA DC-8 aircraft during the Arctic Research of the Composition of the Troposphere from Aircraft and Satellites (ARCTAS) mission in Spring and Summer 2008. We focus on biomass burning plumes encountered during ARCTAS as biomass burning represents one of the largest sources of OA as well as BC (Bond et al., 2004). Wildfires are thus a major global source of absorbing aerosol. Differences in biomass burning plume chemistry and age will be used to explain differences in AAE values between plumes, providing insight into how the role of biomass burning aerosol in climate and photochemistry may change with time. As the prevalence of biomass burning is expected to increase with climate change (Turetsky et al., 2011), understanding the spectral absorption of biomass burning aerosol and its evolution with age is necessary for future climate and photochemical models.

\section{Methods}

\subsection{Measurements}

SSA retrievals were performed using actinic flux as well as aerosol optical properties measured aboard the NASA DC-8 aircraft during the two main phases of ARCTAS: ARCTAS-A (April 2008) and ARCTAS-B (June-July 2008). Flights performed during ARCTAS-A primarily focused on the characterization of arctic haze, long range transport and high bromine oxide events while ARCTAS-B focused on the characterization of biomass burning emissions from boreal forests in north-central Canada. A more detailed description of the ARCTAS mission and instrumentation can be found in Jacob et al. (2010).

Actinic flux was measured using the CCD Actinic Flux Spectrometer (CAFS) aircraft system. The CAFS aircraft system measures spectrally resolved downwelling and upwelling actinic flux using one hemispheric $(2 \pi$ steradian) optical collector mounted to the top and another to the bottom of the DC-8 fuselage, respectively (Shetter and Muller, 1999). Upwelling and downwelling actinic fluxes were reported every $3 \mathrm{~s}$ and every $\sim 0.8 \mathrm{~nm}$ between 280 and $600 \mathrm{~nm}$. The CAFS resolutions at full-width at half maximum (FWHM) were 1.7 and $2.4 \mathrm{~nm}$ in the UV and visible, 
respectively. Upwelling and downwelling actinic flux values were linearly interpolated and added together to produce total fluxes at $1 \mathrm{~nm}$ resolution. Retrievals were not performed for wavelengths $<350 \mathrm{~nm}$ to minimize interferences due to strongly absorbing gases (e.g., $\mathrm{O}_{3}$ ) at shorter UV wavelengths. Additionally, retrievals were not performed for wavelengths $>550 \mathrm{~nm}$ due to low aerosol optical depths at these wavelengths as discussed below. Thus, only total fluxes between 350 and $550 \mathrm{~nm}$ were considered here.

A TSI 3-wavelength nephelometer and a Radiance Research 3-wavelength Particle Soot Absorption Photometer (PSAP) were also aboard the DC-8 during ARCTAS and were used to measure $b_{\text {scat }, 450,550,700}$, and $b_{\text {abs, } 470,532,660}$, respectively. Details about their operation during ARCTAS can be found elsewhere (Jacob et al., 2010). Dry $b_{\text {scat }, \lambda}$ reported by the nephelometer was corrected for angular truncation following the method of Anderson and Ogren (1998) and ambient $b_{\text {scat }, \lambda}$ values were determined from the dry $b_{\text {scat, }, \lambda}$ values using methods outlined in Shinozuka et al. (2007). PSAP $b_{\mathrm{abs}, \lambda}$ values were corrected for artifacts associated with filter-based absorption methods following Lack et al. (2008). In order to determine $b_{\text {ext }, \lambda}$ at $550 \mathrm{~nm}$ required by the radiative transfer code, $b_{\mathrm{abs}, \lambda}$ was corrected to the nephelometer wavelengths using the equation:

$b_{\text {abs }, \lambda}=\left(\frac{\lambda}{470}\right)^{\mathrm{AAE}_{470-660}} b_{\text {abs, } 470}$

where $\mathrm{AAE}_{470-660}$ is the two-wavelength absorption Angstrom exponent between the PSAP wavelengths of 470 and $660 \mathrm{~nm}$ calculated using the general Angstrom exponent (AE) formula:

$\mathrm{AE}=-\frac{\ln \left(n_{\lambda_{1}}-n_{\lambda_{2}}\right)}{\ln \left(\lambda_{1}-\lambda_{2}\right)}$

where $n$ is optical quantity of interest (i.e., aerosol optical depth (AOD), $b_{\text {scat }, \lambda}, b_{\text {abs }, \lambda}, b_{\text {ext }, \lambda}$ ).

An Aerodyne High Resolution Time-of-Flight Aerosol Mass Spectrometer (AMS) aboard the DC-8 was used to measure non-refractory submicron aerosol chemical composition, including OA (Cubison et al., 2011). Details on the AMS technique can be found elsewhere (Canagaratna et al., 2007).

\subsection{SSA retrieval}

A schematic of the retrieval used in this work is shown in Fig. 1. A similar retrieval method was outlined in Corr et al. (2009). High resolution SSA values at 200 UV and visible wavelengths were retrieved by comparing measured actinic flux to those modeled as a function of SSA and the asymmetry parameter $(g)$ using the 4-stream discrete ordinate solver of the Tropospheric Ultraviolet and Visible version 5.0 radiative transfer model (TUV 5.0) (Madronich and Flocke, 1999; http://cprm.acd.ucar.edu/Models/TUV/). Actinic flux was modeled over the wavelength range 350 to

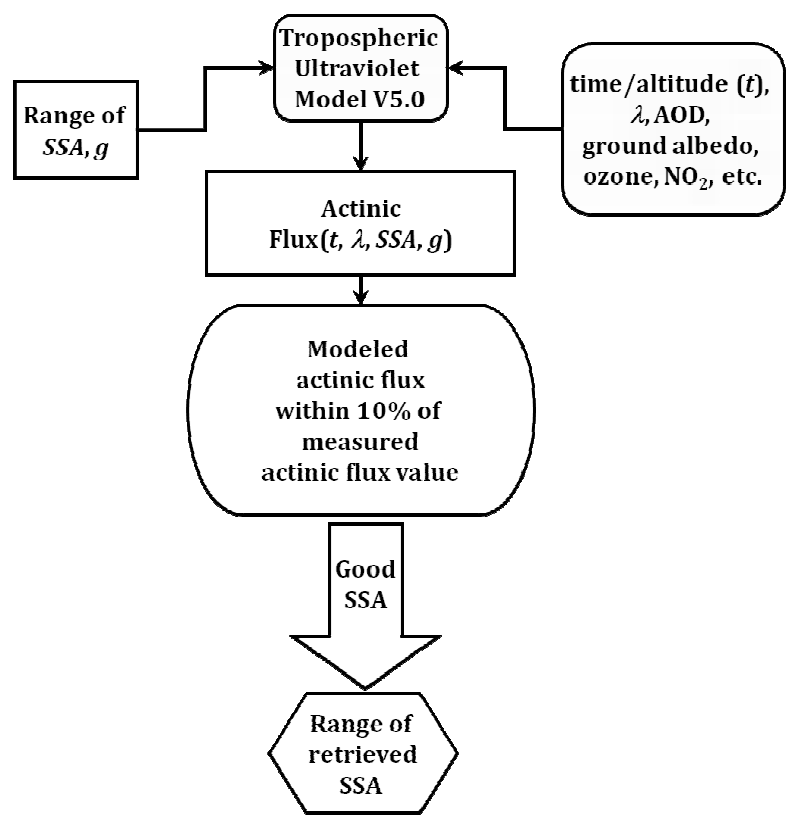

Fig. 1. Schematic of the actinic flux retrieval.

$550 \mathrm{~nm}$ at $1 \mathrm{~nm}$ resolution using $1201 \mathrm{~km}$ thick atmospheric layers positioned between the surface and the maximum altitude. Location specific inputs (e.g., latitude, longitude, surface elevation, UTC time, and aircraft altitude) were taken from the aircraft navigational dataset. TUV output height was taken as the aircraft altitude thus producing retrieved spectral SSA at each point along the aircraft track. Column $\mathrm{O}_{3}, \mathrm{NO}_{2}$, and $\mathrm{SO}_{2}$ concentrations were estimated from the daily images produced from the Ozone Monitoring Instrument (OMI) aboard the NASA Aura satellite. The coarse resolution of these data and the imprecise estimation of values may introduce some error into the retrievals. However, sensitivity studies showed modeled actinic flux for the wavelength range considered here was unaffected by large variations in column $\mathrm{O}_{3}$ and $\mathrm{SO}_{2}$ concentrations. Modeled actinic flux did show slight variation $(<2 \%)$ over a large range in $\mathrm{NO}_{2}$ column concentration (0-2 DU) however, actual variability in $\mathrm{NO}_{2}$ column concentrations, and the corresponding variation in modeled actinic flux, are expected to be much smaller. Thus, possible error associated with the TUV 5.0 trace gas column concentration inputs are expected to be negligible.

Aerosol- (excluding SSA and the asymmetry parameter) and surface-related input parameters were primarily computed from in-situ aircraft data during aircraft spiral profiles. Spiral profiles were used to limit the extent of the aircraft's horizontal coverage to ensure accuracy in the AOD and surface albedo calculations discussed below. $b_{\text {ext, } 450}$ and $b_{\text {ext, } 550}$ were vertically integrated to calculate AOD at those wavelengths. AOD at $1 \mathrm{~nm}$ resolution from 350 to $550 \mathrm{~nm}$ were estimated using $\mathrm{AOD}_{450}$ and $\mathrm{AOD}_{550}$ as well as the $\mathrm{AOD}$ Angstrom exponent (see Eq. 2). The spectral AOD values 
were subsequently vertically interpolated using a version of the TUV 5.0 default Elterman et al. (1969) $b_{\text {ext,550 profile }}$

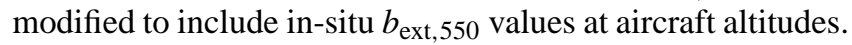
It is important to note that, since these AOD values do not consider aerosols above and below the spiral profile they likely underestimate the true AOD. However, as the identified plumes were typically strong, we assumed contributions to AOD from unsampled aerosol were only $\sim 10 \%$. This error in AOD was accounted for in the retrieval threshold described below. Additional errors may be associated with the extrapolation of AOD from the visible into the UV. While the wavelength range over which we extrapolate in this work is narrow $(\leq 100 \mathrm{~nm})$, the use of an AOD Angstrom exponent calculated at two visible wavelengths may result in incorrect values of the UV AOD for aerosols with strong spectral absorption, such as those examined here. However, sensitivity tests performed for two biomass burning events identified in Eck et al. (1999) demonstrated that the 440-500 nm AOD Angstrom exponent calculated from AERONET AOD reproduced AERONET AOD at $380 \mathrm{~nm}$ within $\sim 3 \%$. Further, Krotkov et al. (2005a) showed that the linear extrapolation of AERONET AOD over a small wavelength range $(<100 \mathrm{~nm})$ produced AOD values in close agreement with those measured to wavelengths as low as $325 \mathrm{~nm}$ using a UV multifilter shadowband radiometer for urban aerosols. Thus errors in UV AOD due to extrapolation from the visible over the wavelength range used here are likely small.

Snow surface albedo values measured during ARCTASA from the NASA P-3B aircraft were used to retrieve SSA for ARCTAS-A flights (Lyapustin et al., 2010). As shown in Fig. 2 of Lyapustin et al. (2010), snow albedo had minimal spectral dependence over the retrieval wavelength range, thus snow surface albedo was assumed to be spectrally invariant in TUV 5.0. Areal surface albedo $\left(\rho_{\text {surf }, \lambda}\right)$ values at $450 \mathrm{~nm}$ and $550 \mathrm{~nm}$ were determined for ARCTAS-B flights using actinic flux measurements and the equation

$\rho_{\text {surf }, \lambda}=\frac{F_{\text {calc }} \downarrow\left(z_{\text {flight }}\right)}{F_{\text {calc }} \uparrow\left(z_{\text {flight }}\right)} \times \frac{F_{\text {meas }} \uparrow\left(z_{\text {flight }}\right)}{F_{\text {meas }} \downarrow\left(z_{\text {flight }}\right)} \times \frac{F_{\text {calc }} \uparrow\left(z_{0}\right)}{F_{\text {calc }} \downarrow\left(z_{0}\right)}$

where $F_{\text {calc }}$ is modeled actinic flux, $F_{\text {meas }}$ is the measured actinic flux, $z_{0}$ is the surface, $z_{\text {flight }}$ is the aircraft altitude and $\downarrow$ and $\uparrow$ denote downwelling and upwelling, respectively (Wendisch et al., 2004). Modeled actinic flux values were determined using TUV 5.0 and SSA and AOD values calculated using the scattering and absorption in-situ data described above. Surface albedo values at $450 \mathrm{~nm}$ and $550 \mathrm{~nm}$ were calculated as average of the $\rho_{\text {surf, } \lambda}$ values below an aircraft altitude of $2 \mathrm{~km}$. These values were linearly interpolated to produce spectral surface albedo between $350 \mathrm{~nm}$ and $550 \mathrm{~nm}$ at $1 \mathrm{~nm}$ resolution. Spectral surface albedo values calculated in this way for ARCTAS-B flights compared well to those measured in boreal regions (Betts and Ball, 1997; Moody et al., 2007). Areal surface albedo was also determined for the ARCTAS-A flight of interest, 17 April, to
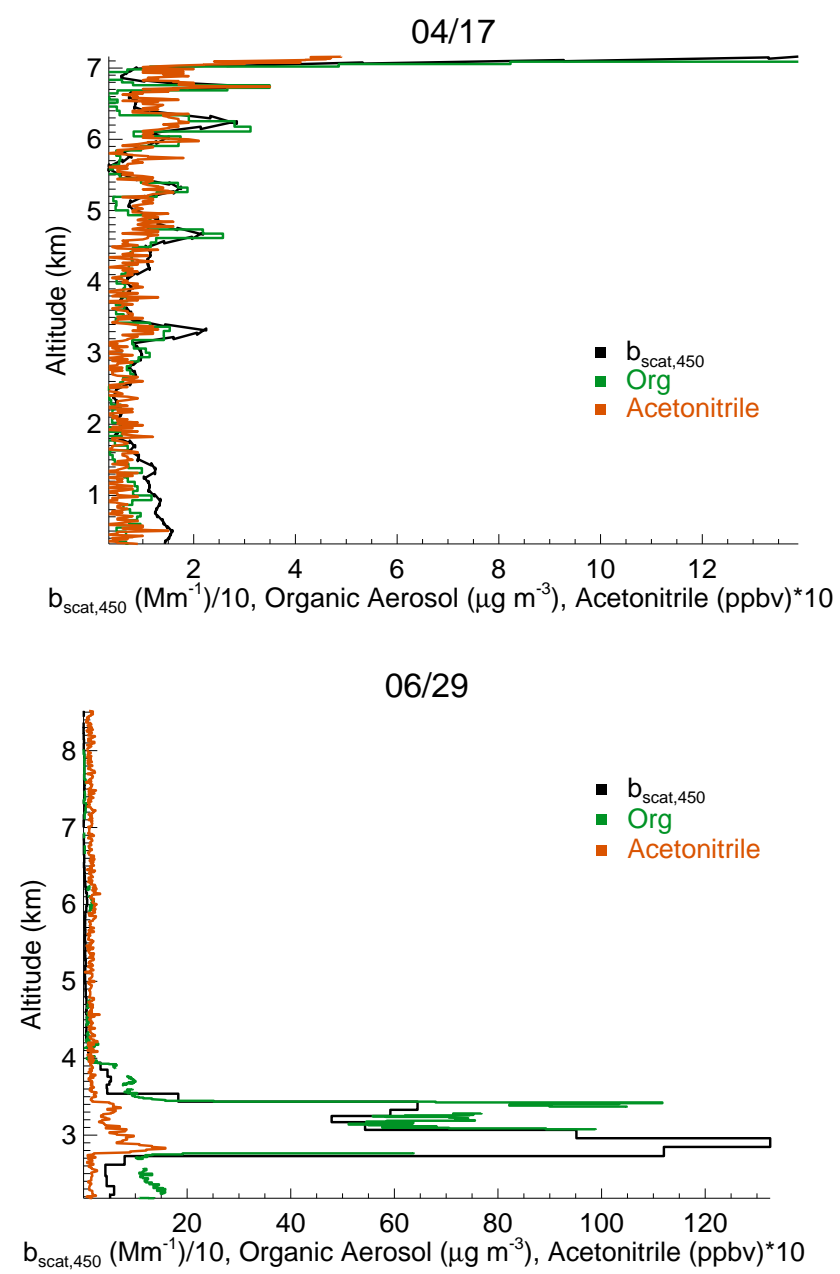

Fig. 2. Vertical profiles of $b_{\text {scat }, 450}$ (black), organic aerosol (green), and acetonitrile (orange) for 17 April (top) and 29 June (bottom) spiral profiles.

estimate the error associated with calculated surface albedo. Surface albedo calculated using Eq. (3) for 17 April were approximately $10 \%$ lower than those reported by Lyapustin et al. (2010), thus a $\pm 10 \%$ error was assigned to surface albedo values. Like AOD, the retrieval threshold value accounted for this $\pm 10 \%$ in surface albedo.

Ranges of the two remaining input parameters, SSA and $g$, were used in TUV 5.0 to produce modeled actinic flux values as a function of these two aerosol parameters. Studies have shown that wide variations in $g$ have little impact on SSA retrieved using methods similar to this work's (Bergstrom et al., 2003; Barnard et al., 2008; Corr et al., 2009; Buchard et al., 2011). Nonetheless, values of $g$ ranging from $0.6-0.75$ were tested to assess possible variations in actinic flux with variations in $g$ associated with biomass burning aerosols. Johnson et al. (2008) found $g$ values of $0.57-0.66$ for both fresh and aged biomass burning aerosols. Similarly, Haywood et al. (2003) determined mean $g$ values 
of 0.64 and 0.58 at $450 \mathrm{~nm}$ and $550 \mathrm{~nm}$, respectively for several aircraft flights through biomass burning plumes. Osborne and Haywood (2005) showed that for larger (mean diameter $\geq 0.5 \mu \mathrm{m}$ ) biomass burning particles $g$ ranged from $0.71-0.86$. Small $(<\sim 2 \%)$ variations in actinic flux over this wide range in $g$ were observed in sensitivity studies performed for all wavelengths. Additionally, variations in SSA (0.5-1.0) caused variations in actinic flux well over 50 times greater than those caused by variations in $g$ thus influences of $g$ on retrieved SSA were assumed to be minimal.

An SSA range of 0.5-1.0 was used to represent the wide range in SSA for biomass burning aerosols found in the literature (e.g., Bergstrom et al., 2003; Johnson et al., 2008; Lewis et al., 2008; Eck et al., 2009; Mack et al., 2010; Alados-Arboledas et al., 2011; Tesche et al., 2011). The differences in SSA among biomass burning aerosols is likely explained by observed differences in combustion conditions generated by different fuel types, humidities, etc. as well as plume age (Reid and Hobbs, 1998; Eck et al., 2003; Kirchstetter et al., 2004; Chen et al., 2006; Lewis et al., 2008; Mack et al., 2010). For instance, in recent laboratory studies, the combustion of 14 different types of biomass fuel yielded a range in SSA 0.37-0.95 (Lewis et al., 2008; Mack et al., 2010). However, as discussed in Sect. 3, field measurements and remote sensing retrievals indicate SSA rarely falls below $\sim 0.6$ in ambient plumes.

Prior to comparison, both modeled and measured actinic fluxes were smoothed in wavelength using a 3-point running mean to account for slight offsets between the TUV 5.0 and CAFS wavelength grids as well as the wavelength dependence of the CAFS FWHM. This smoothing procedure also aimed to reduce the influence of non-aerosol sharp spectral features (e.g., Fraunhofer lines) on retrieval parameters, though such features were not completely removed as discussed below. The resulting smoothed modeled and measured actinic fluxes from 350 to $550 \mathrm{~nm}$ were compared to retrieve SSA. SSAs were considered retrieved where modeled actinic flux matched measured within $10 \%$. This $10 \%$ criterion was chosen based on sensitivity studies (not shown) that showed a $10 \%$ error in AOD together with $10 \%$ error in assumed and calculated surface albedos resulted in changes to modeled actinic flux value by $\leq 10 \%$. This comparison produced ranges in SSAs at each wavelength that were subsequently averaged to produce mean $\operatorname{SSA}(\lambda)$ values for each spiral profile altitude.

\subsection{Case studies}

To ensure valid retrievals, spiral profiles were screened to meet the following criteria: (1) $\mathrm{AOD}_{550} \geq 0.1$, and (2) cloudfree conditions within the spiral profile. The $\mathrm{AOD}_{550} \geq 0.1$ threshold was adopted from Corr et al. (2009) who showed SSA values were irretrievable using irradiance data when their $\mathrm{AOD}_{368}$ fell below 0.1. A similar result was seen with the ARCTAS actinic flux (not shown), thus we apply the
$\mathrm{AOD}_{550} \geq 0.1$ threshold in this work to ensure valid retrievals over the entire wavelength range considered here.

Cloud-free conditions were identified using the Cloud and Aerosol Precipitation Spectrometer (CAPS; DMT, Boulder, $\mathrm{CO}$ ) cloud index product where cloud index values equal to zero are associated with liquid- and ice-water-content less than $0.01 \mathrm{~g} \mathrm{~m}^{-3}$. While the cloud index identifies clouds encountered during the spiral profile, it does not indicate the presence of clouds outside the spiral profile. Lofted clouds, including high altitude thin cirrus, as well as low stratus clouds can substantially impact the radiation field (e.g., Lopez et al., 2009; Flynn et al., 2010) and may therefore impact retrieved SSA. However, we assume the influence of distant clouds on actinic flux is minor compared to the aerosol in optically thick aerosol plumes, such as the ones examined in this work.

Based on these criteria, two useable spiral profiles were identified: one during ARCTAS-A on 17 April 2008 (21:1421:33 UTC, hereafter 17 April and one during ARCTASB on 29 June 2008 (22:30-22:43 UTC) hereafter 29 June. A biomass burning plume was identified for each case using aerosol and gas-phase data collected aboard the DC-8. Biomass burning plumes were defined as regions within the spiral profile that had co-located elevated (greater than the spiral profile mean value plus 1 standard deviation) biomass burning markers including acetonitrile, OA, and $b_{\text {scat, } 450}$ (Fig. 2). Maximum concentrations of these biomass burning tracers as well as plume altitudes are listed in Table 1. Plume identification and back trajectory analysis performed by Hornbrook et al. (2011) indicated the 17 April plume examined here was a $\sim 6$ day old Siberian forest fire plume. In contrast, measurements during the 29 June case were made directly above an active fire in Saskatchewan, a plume less than $3 \mathrm{~h}$ old (Hornbrook et al., 2011). It is important to note that the 17 April plume was intersected at the top of the spiral profile and it is unclear whether the entire plume was sampled. As a result, there may be some additional error in the 17 April retrieval due to errors in AOD that exceed the established $10 \%$ criteria. However, retrievals performed for the 17 April case under a doubled AOD scenario did not alter the spectral dependencies in retrieved parameters, though increases (decreases) were seen in retrieved SSA $\left(b_{\mathrm{abs}, \lambda}\right)$. We report the 17 April results using the AOD calculated from in-situ measurements with the understanding that they likely yield upper limit estimates of aerosol absorption for the plume.

\section{Results}

Mean $\operatorname{SSA}(\lambda)$ retrieved at all altitudes identified as in-plume were averaged to estimate mean spectral SSA in each plume for 17 April and 29 June (Figs. 3, 4). It is important to first note the high frequency spectral variability seen in the mean in-plume SSA spectra for both cases. While such variability 
Table 1. In-plume mean altitude, $b_{\text {scat } 450}$ and concentrations of $\mathrm{OA}, \mathrm{BC}$, acetonitrile, $\mathrm{NO}_{2}$, and $\mathrm{O}_{3}$. In-plume ranges are shown in parentheses.

\begin{tabular}{lll}
\hline & 17 April & 29 June \\
\hline Plume Altitude $(\mathrm{km})$ & $7.10(7.05-7.16)$ & $3.12(2.82-3.41)$ \\
$b_{\text {scat }, 450\left(\mathrm{Mm}^{-1}\right)}$ & $90.5(27.0-141.4)$ & $1186.6(678.6-2174.8)$ \\
$\mathrm{OA}\left(\mu \mathrm{g} \mathrm{s} \mathrm{m}^{-3}\right)$ & $14.7(4.9-22.2)$ & $72.3(51.2-104.9)$ \\
$\mathrm{BC}\left(\mathrm{ng} \mathrm{m}^{-3}\right)$ & $797(305-1208)$ & $6974(5278-8654)$ \\
Acetonitrile (pptv) & $367(220-490)$ & $643(300-1580)$ \\
$\mathrm{NO}_{2}$ (pptv) & $32(18-44)$ & $95(47-186)$ \\
$\mathrm{O}_{3}$ (ppbv) & $93.6(74.0-118.9)$ & $81.8(63.4-95.6)$ \\
\hline
\end{tabular}

may in part be due to aerosol, it more likely reflects the influence of non-aerosol spectral features inherent to actinic flux measurements (e.g., Fraunhofer lines). Despite this nonaerosol variability, SSA spectral dependencies within each plume, as well as relationships between the two cases can be identified. For both cases, in-plume mean SSA values retrieved for UV wavelengths are lower than those determined for visible wavelengths $\leq 500 \mathrm{~nm}$. The largest difference is seen on 17 April, which had a mean UV SSA $(350 \leq \lambda<$ $400 \mathrm{~nm})$ of 0.83 and a mean visible SSA $(400 \leq \lambda \leq 500 \mathrm{~nm})$ of 0.93. Differences between UV SSA and visible SSA were smaller but still statistically significant $(p<0.001)$ on 29 June, with values of 0.84 and 0.88 , respectively. Comparing the two case studies, visible SSA is much higher on 17 April than on 29 June, while UV SSA on 29 June is higher than on 17 April, though the latter difference is not statistically significant.

SSA values calculated from in-situ data were compared to those retrieved to examine the validity of the retrieval results. As shown in Fig. 3, SSA values at $470 \mathrm{~nm}$ and $532 \mathrm{~nm}$ compared well to those retrieved at the same wavelengths for 17 April. In-situ SSA at $470 \mathrm{~nm}$ and $532 \mathrm{~nm}$ were slightly higher than those mean retrieved values for 29 June (Fig. 4). However, minimum in-situ SSA at $470 \mathrm{~nm}$ and $532 \mathrm{~nm}$ (shown as the bottom error bars on in-situ SSA in Fig. 4) values measured in the plume are nearly as low as mean retrieved SSA at the same wavelengths indicating similarly low SSAs were measured in the 29 June plume.

For both cases, there is a notable decrease in SSA between 500 and $550 \mathrm{~nm}$ to values that are comparable with UV SSA. While this "tailing" may point to valid and important variations in retrieved SSA beyond $500 \mathrm{~nm}$, it may also suggest retrieval error at longer wavelengths as absorption by non-BC aerosol at visible wavelengths is expected to be low. The source of a retrieval error at these wavelengths is unclear, however, the degree of impact appears related to AOD. The most pronounced decrease in SSA between $500 \mathrm{~nm}$ and $550 \mathrm{~nm}$ occurred on 17 April $(\sim 18 \%)$, when AOD averaged across the same wavelength $\left(\mathrm{AOD}_{500-550}\right)$ range was only 0.11 . In contrast, SSA only decreased $\sim 5 \%$ between $500 \mathrm{~nm}$ and $550 \mathrm{~nm}$ on 29 June which had an $\mathrm{AOD}_{500-550}$ of

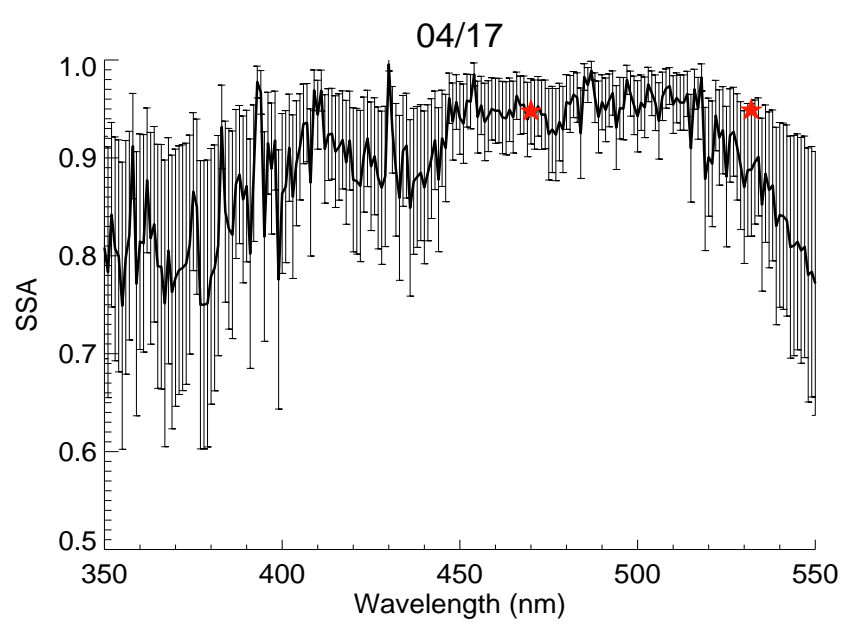

Fig. 3. Retrieved in-plume average SSA for 17 April. Error bars represent the standard deviation of all retrieved in-plume SSA values. Orange stars represent SSA calculated from measured $b_{\text {scat }}$ and $b_{\text {abs. }}$. Maximum and minimum SSA values measured for the plume are shown by orange error bars. For 17 April, maximum and minimum SSA values were close for both wavelengths (Ranges: 0.946$0.951(470 \mathrm{~nm})$ and $0.947-0.952(532 \mathrm{~nm}))$ and thus are not visible on the graph.

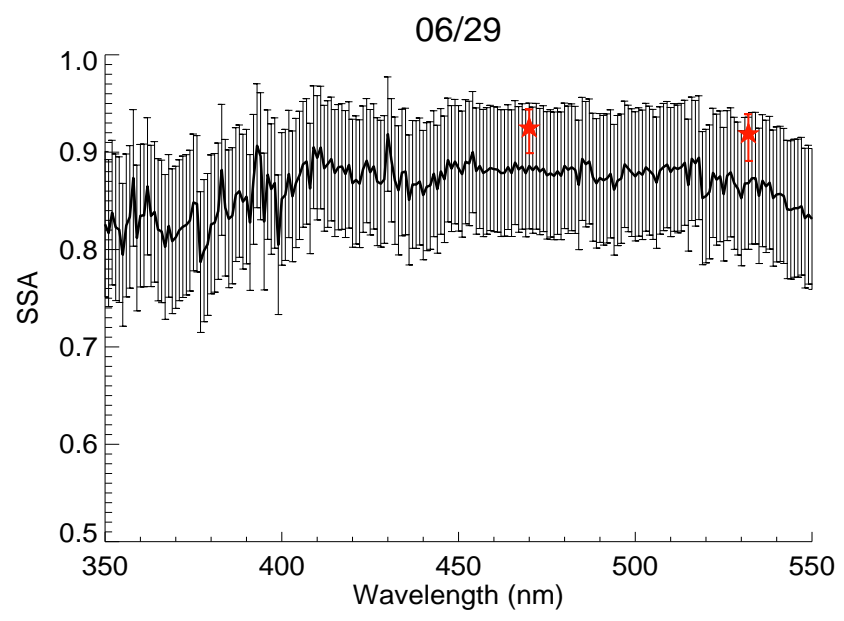

Fig. 4. Retrieved in-plume average SSA for 29 June. Error bars represent the standard deviation of all retrieved in-plume SSA values. Orange stars represent SSA calculated from measured $b_{\text {scat }}$ and $b_{\text {abs }}$. Maximum and minimum SSA values measured for the plume are shown by orange error bars.

0.81. Sensitivity studies (not shown) indicate that, as AOD decreases, modeled actinic flux becomes increasingly insensitive to SSA, resulting in an increase in the range in retrieved SSA values. Mean SSA values may therefore appear artificially low as values approach the mean of the entire tested SSA range (here 0.75) with a decrease in AOD. This may suggest that an AOD criteria $\gg 0.1$ is needed to improve accuracy in actinic flux retrievals at longer wavelengths. 
Retrieved SSAs for both 17 April and 29 June generally compare well to SSA values previously measured and retrieved for biomass burning aerosol. For instance, in-plume mean SSA retrieved at $355 \mathrm{~nm}$ for 17 April $(0.75 \pm 0.15)$ and 29 June $(0.79 \pm 0.07)$ agreed with the range of values retrieved using Raman Lidar at the same wavelength by Alados-Arboledas et al. (2011) (0.76-0.83) and Tesche et al. (2011) (0.63-0.89). For both cases, SSA retrieved at $350 \mathrm{~nm}(0.81 \pm 0.12$ for 17 April and $0.83 \pm 0.07$ for 29 June were slightly lower than those reported by Bergstrom et al. (2003) for aged West African biomass burning aerosol (0.85-0.90), possibly due to differences in atmospheric chemical processing, fuel type (savannah grasses in Bergstrom et al. (2003) versus the boreal forest emissions examined here), and/or combustion intensity. Despite possible retrieval errors at wavelengths $>500 \mathrm{~nm}$, retrieved SSA values for both cases also show good agreement with those retrieved at longer visible wavelengths. For instance, SSA reported at $532 \mathrm{~nm}$ by Alados-Arboledas et al. (2011) $(0.80-0.87)$ were similar to the values of $0.89 \pm 0.07$ for 17 April and $0.87 \pm 0.07$ for 29 June. Retrieved SSA at $550 \mathrm{~nm}(0.77 \pm 0.13$ for 17 April and $0.83 \pm 0.07$ for 29 June $)$ agreed well with Johnson et al. (2008) range of 0.73-0.93 reported at the same wavelength. However, retrieved SSA values for both cases at $550 \mathrm{~nm}$ were much lower than the range of 0.91-0.99 reported by Eck et al. (2009), though this may be explained by larger aged particles measured by Eck et al. (2009), fuel type (peat in Eck et al., 2009), and/or different combustion conditions.

The lower UV SSA values seen in both cases suggest enhanced aerosol absorption at shorter wavelengths $(\lambda<400 \mathrm{~nm})$. To examine this, spectral $(350-500 \mathrm{~nm})$ $b_{\text {abs, } \lambda}$ was calculated using in-plume mean $\operatorname{SSA}(\lambda)$ and $b_{\text {ext }, \lambda}$ and a modified version of the definition of SSA (Russell et al., 2010).

$b_{\mathrm{abs}, \lambda}=[1-\operatorname{SSA}(\lambda)] b_{\mathrm{ext} \lambda}$

Spectral $b_{\text {abs }, \lambda}$ was not determined for $500-550 \mathrm{~nm}$ due to the possible errors over this wavelength discussed above. As seen in Fig. 5, $b_{\mathrm{abs}, \lambda}$ values at UV wavelengths are much higher than those calculated at visible wavelengths on both days, despite large differences in the magnitude of $b_{\mathrm{abs}, \lambda}$ between the two cases. Furthermore, average UV $b_{\mathrm{abs}, \lambda}(350 \leq$ $\lambda<400 \mathrm{~nm}$ ) were $\sim 3$ and 2 times greater than average visible $b_{\text {abs }, \lambda}(400 \leq \lambda \leq 500 \mathrm{~nm})$ for 17 April and 29 June, respectively, indicating stronger spectral aerosol absorption in the 17 April plume. Greater relative absorption in the UV is reflected in a higher AAE $(350-500 \mathrm{~nm})$ on 17 April $\left(6.78 \pm 0.38, r^{2}=0.68\right)$ than on 29 June $\left(3.34 \pm 0.11, r^{2}=\right.$ 0.86 ), calculated for each case as the slope of a linear fit through a plot of $b_{\mathrm{abs}, \lambda}$ versus wavelength in log space across the wavelength range $350-500 \mathrm{~nm}$ (Bergstrom et al., 2007; Russell et al., 2010) (Table 2). It is important to note that in-plume AAE values for both 17 April and 29 June were

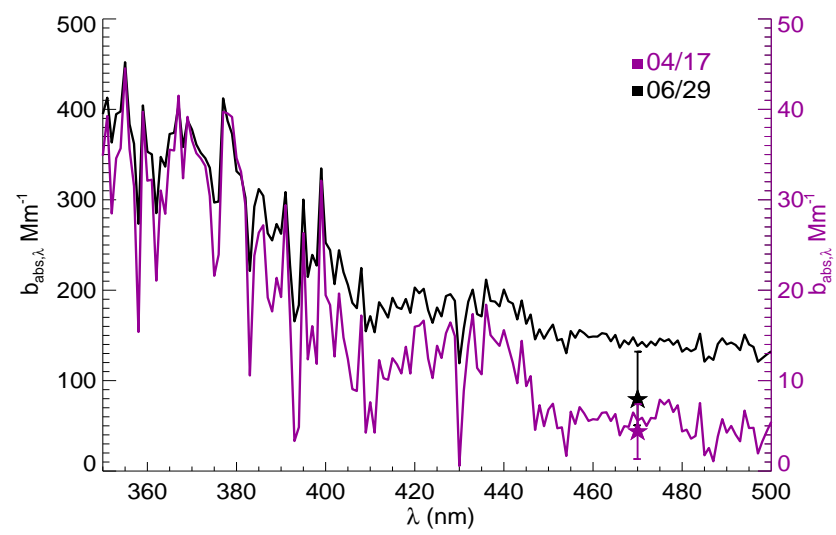

Fig. 5. Spectral $b_{\mathrm{abs}, \lambda}$ calculated from retrieved in-plume average SSA for 17 April (purple, right axis) and 29 June (black, left axis). Mean PSAP $b_{\text {abs, } 470}$ for 17 April and 29 June are shown as a purple and black star, respectively. Maximum and minimum $b_{\mathrm{abs}, 470}$ values measured for the plume are shown by error bars.

greater than 1 , indicating greater spectral absorption than can be explained by black carbon (Kirchstetter et al., 2004). AAE values calculated for two wavelength pairs $(470-532 \mathrm{~nm}$ and $470-660 \mathrm{~nm}$ ) using in-situ $b_{\mathrm{abs}, \lambda}$ data and Eq. (2) also show enhanced spectral absorption, however, they are consistently lower than those determined using retrieved SSA (Table 2). This offset between AAE calculated using retrieval results and those calculated using in-situ data may at least partially be explained by the different wavelength ranges considered in the AAE calculations as discussed below.

In-plume AAE retrieved for 29 June as well as in-situ AAE for both plumes (Table 2) compare well to Lewis et al. (2008) who found a range in AAE of $\sim 1-3.5$ for the wavelength pair 405-870 nm for various biomass burning fuel types in a chamber study. Similarly, Kirchstetter et al. (2004) reported AAEs over the wavelength range $\sim 330-1000 \mathrm{~nm}$ of $\sim 1.8$ 3.0 for filter samples of fresh biomass burning aerosol. Ambient AAE values as high as 3.7 were seen at an Alpine site dominated by wood smoke for the wavelength range 370$530 \mathrm{~nm}$ (Sandradewi et al., 2008). In-plume AAE retrieved for 17 April was much higher than those previously measured for biomass burning aerosol (e.g., Kirchstetter et al., 2004; Lewis et al., 2008; Sandradewi et al., 2008) which may suggest error in the retrieval either due to UV-absorbing gases or low AOD on 17 April. Several studies have reported higher (>6) AAE values for both water and methanol extracts of biomass burning aerosol comparable to the 17 April in plume retrieved AAE over the wavelength ranges $~ 300$ $800 \mathrm{~nm}$ (Hoffer et al., 2006; Chen and Bond, 2010; Hecobian et al., 2010). However, as shown in Chen and Bond (2010), such extractions may isolate only certain types of aerosols and thus AAE values determined from extracts may not fully represent the spectral absorption of a biomass burning plume 
Table 2. Retrieved and in-situ AAE values for 17 April and 29 June.

\begin{tabular}{lrr}
\hline & 17 April & 29 June \\
\hline Retrieved AAE & $6.78 \pm 0.38$ & $3.34 \pm 0.11$ \\
AAE $_{470-532}$ & 1.94 & 1.38 \\
AAE $_{470-660}$ & 1.65 & 1.26 \\
\hline
\end{tabular}

in the atmosphere. Thus, some caution should be taken when interpreting the 17 April results.

In-plume retrieved AAE values were much higher than those determined for biomass burning aerosol over the wavelength range 325-1000 $\mathrm{nm}$ (1.45) by Bergstrom et al. (2007) and Russell et al. (2010) using the same linear fit method described above. This difference may, in part, be due to the consideration of longer visible wavelengths $(\lambda>600 \mathrm{~nm})$ in the linear fit, which may act to dampen the strong absorption signature seen at shorter wavelengths. In fact, both Bergstrom et al. (2007) and Russell et al. (2010) showed this effect through the calculation of a smaller AAE (1.1) over a larger wavelength range (325-1685 nm) for the same biomass burning plume. Additionally, Lewis et al. (2008) found larger AAE values for the wavelength pair $405-870 \mathrm{~nm}$ than 532$870 \mathrm{~nm}$, a finding the authors attributed to stronger absorption at shorter wavelengths. Sandradewi et al. (2008) also found large increases to AAE values (2.2 to 3.7) with a decrease in wavelength range $(370-950 \mathrm{~nm}$ to $370-530 \mathrm{~nm}$ ) calculated during the wood-smoke-dominated winter period at an Alpine site.

\section{Discussion}

\subsection{Contribution of OA to spectral absorption}

Several laboratory and field investigations have attributed enhanced spectral absorption in biomass burning aerosol to OA (e.g., Kirchstetter et al., 2004; Hoffer et al., 2006; Lewis et al., 2008). Kirchstetter et al. (2004), and later Lewis et al. (2008), showed biomass burning with the greatest OA concentrations had the highest AAE values. Clarke et al. (2007) described an increase in absorption with an increase in non-volatile OA, with the greatest absorption increases at their shortest wavelength $(470 \mathrm{~nm})$. Hoffer et al. (2006) estimated that OA could account for as much as $50 \%$ of short-wavelength absorption in Brazilian biomass burning aerosol extracts with AAE values of 6.4-6.8. Similarly, Favez et al. (2009) reported agricultural biomass burning aerosol generated from the combustion of rice straw near Cairo, Egypt was responsible for at least $26 \%$ of aerosol absorption at $370 \mathrm{~nm}$ with contributions as high as $50 \%$ during large burning events.
To investigate the influence of OA on spectral absorption for the 17 April and 29 June biomass burning plumes, spectral $(350-500 \mathrm{~nm}) b_{\mathrm{abs}, \lambda}$ attributed to OA $\left(b_{\mathrm{abs}, \mathrm{OA}, \lambda}\right)$ was estimated using previously established methods (Clarke et al., 2007; Yang et al., 2009; Arola et al., 2011). First, spectral $b_{\mathrm{abs}, \lambda}$ due to $\mathrm{BC}\left(b_{\mathrm{abs}, \mathrm{BC}, \lambda}\right)$ was determined by assuming BC dominated the PSAP absorption at $660 \mathrm{~nm}$. Values of $b_{\mathrm{abs}, \mathrm{BC}, \lambda}$ were then calculated via the extrapolation of in-situ $b_{\mathrm{abs}, 660}$ to retrieval wavelengths assuming a $\mathrm{BC}$ AAE of 1 and Eq. (1). While the BC AAE = 1 assumption has been generally accepted as a means to estimate BC absorption contribution (e.g., Clarke et al., 2007; Yang et al., 2009; Arola et al., 2011), studies have shown variability in BC AAE (e.g., Lack and Cappa, 2010). For instance, Lack and Cappa (2010) found that, for BC mixtures and BC containing coatings, BC AAE can be as high as 1.6. Given this, the $b_{\mathrm{abs}, \mathrm{BC}, \lambda}$ calculated here are meant to represent an approximation. The calculated $b_{\mathrm{abs}, \mathrm{BC}, \lambda}$ spectra was subsequently subtracted from the original "total" $b_{\mathrm{abs}, \lambda}$ to estimate

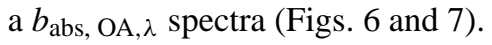

The overall contributions of OA to total spectral absorption were approximated at 57.7\% 17 April and 56.2\% on 29 June (Table 3). For both cases, the OA contribution to absorption was greater in the UV than visible, though this difference was larger for 17 April. While the increase in OA contribution to absorption with decrease in wavelength is consistent with other studies, overall, the absorption attributed to OA in both plumes was higher than previously reported (e.g., Hoffer et al., 2006; Favez et al., 2009). Contributions of OA to absorption are expected to be higher in plumes where concentrations of OA are much higher than BC (Favez et al., 2009). However, such high values may also suggest the presence of strong spectral absorbers in addition to OA such as mineral dust or trace gas-phase species. The high AOD extinction Angstrom exponents (1.59 for 17 April and 2.16 for 29 June, as well as high $(>0.8)$ submicron scattering fractions, determined for both days suggest little dust influence. Additionally, McNaughton et al. (2011) found dust to play a minor, if any, role in aerosol absorption during ARCTASA, largely due to the lack of dust plumes encountered during ARCTAS-A. As stated above, absorption due to the two most common trace gases that absorb at short wavelengths, $\mathrm{O}_{3}$ and $\mathrm{NO}_{2}$, were accounted for in TUV 5.0. While these gases are thought to be most relevant for total column aerosol retrievals, other absorbing gases may need to be considered when retrieving aerosol properties in plumes where concentrations of such gases may be high.

Despite the possible influence of absorbing trace gases, OA contributions show similar trends to those calculated from the PSAP $b_{\mathrm{abs}, \lambda}$ values at $470 \mathrm{~nm}$ and $532 \mathrm{~nm}$ (Table 3 ); the PSAP data confirm (1) OA absorption contributions were higher at shorter wavelengths and (2) overall OA absorption is higher in the 17 April plume. Differences in the overall OA absorption contribution between the two days is likely explained by differences in the biomass burning plumes. As 


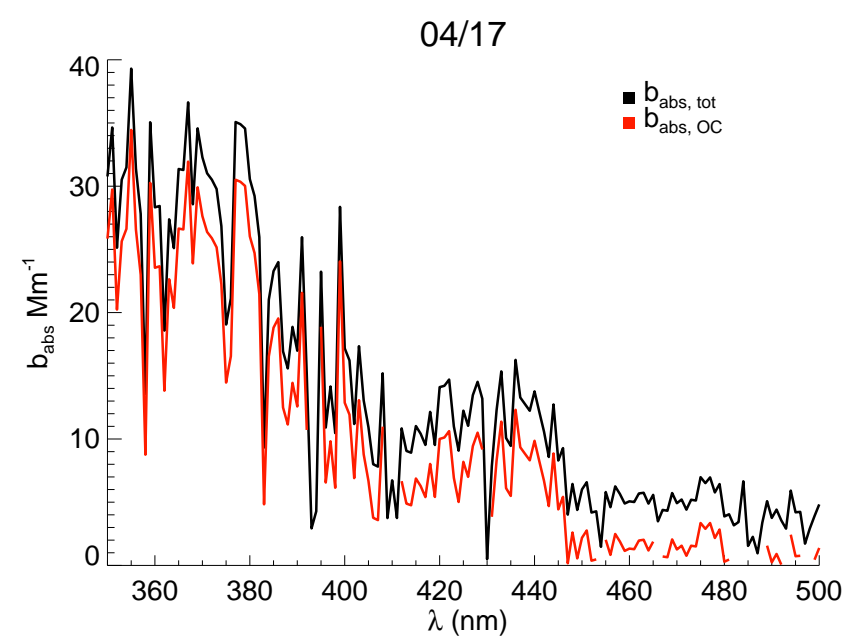

Fig. 6. Spectral $b_{\mathrm{abs}, \mathrm{OC}, \lambda}$ calculated from $b_{\mathrm{abs}, \lambda}$ using methods outlined in Arola et al. (2011) for 17 April. Negative values of $b_{\mathrm{abs}, \mathrm{OC}, \lambda}$ around the sharp dips in the total $b_{\mathrm{abs}, \lambda}$ curve were removed due to their unphysical nature for the $\mathrm{AAE}_{\mathrm{OA}}$ calculation.

expected, the fresh plume on 29 June is associated with overall higher aerosol and trace gas concentrations as seen in Table 1. However, the 17 April plume has a higher OA/BC ratio (15.9) compared to the 29 June plume (10.6), which supports the higher fractional absorption by OA in the first plume (Clarke et al., 2007; Favez et al., 2009; McNaughton et al., 2011).

\subsection{Aerosol oxidation and spectral absorption}

Previous studies (e.g., Clarke et al., 2007; Lewis et al., 2008) have shown a positive relationship between the AAE and the organic-carbon/total-carbon ratio, thus the greater influence of $\mathrm{BC}$ in the 29 June plume may be at least partially responsible for the lower AAE value determined for this plume. However, differences in the OA chemistry between the aged 17 April and the fresh 29 June plume may also play a role. To explore this hypothesis, $\mathrm{OA}$-only $\mathrm{AAE}\left(\mathrm{AAE}_{\mathrm{OA}}\right)$ values were estimated from the retrieval results by applying the AAE calculation methods to $b_{\mathrm{abs}, \mathrm{OA}, \lambda}$ values. It should be noted that for 17 April, the subtraction of the $b_{\mathrm{abs}, \mathrm{BC}, \lambda}$ extrapolated curve from the total $b_{\mathrm{abs}, \lambda}$ curve resulted in negative values of $b_{\mathrm{abs}, \mathrm{OC}, \lambda}$ around the sharp dips in the total $b_{\mathrm{abs}, \lambda}$ curve. Due to their unphysical nature, these values were removed in order to determine the AAE as a linear fit to a plot of $\ln (\lambda)$ versus $\ln \left(b_{\mathrm{abs}, \lambda}\right)$. As expected, $\mathrm{AAE}_{\mathrm{OA}}$ values were higher than the AAE calculated using "total" $b_{\mathrm{abs}, \lambda}$ with a value of $11.15 \pm 0.59\left(r^{2}=0.66\right)$ for 17 April and $4.94 \pm 0.19$ $\left(r^{2}=0.83\right)$ for 29 June. OA-only AAE $470-532$ values were also higher than the "total" $\mathrm{AAE}_{470-532}$ with values of 7.56 and 4.22 for 17 April and 29 June, respectively. Both insitu and retrieved OA-only AAE values are still higher on

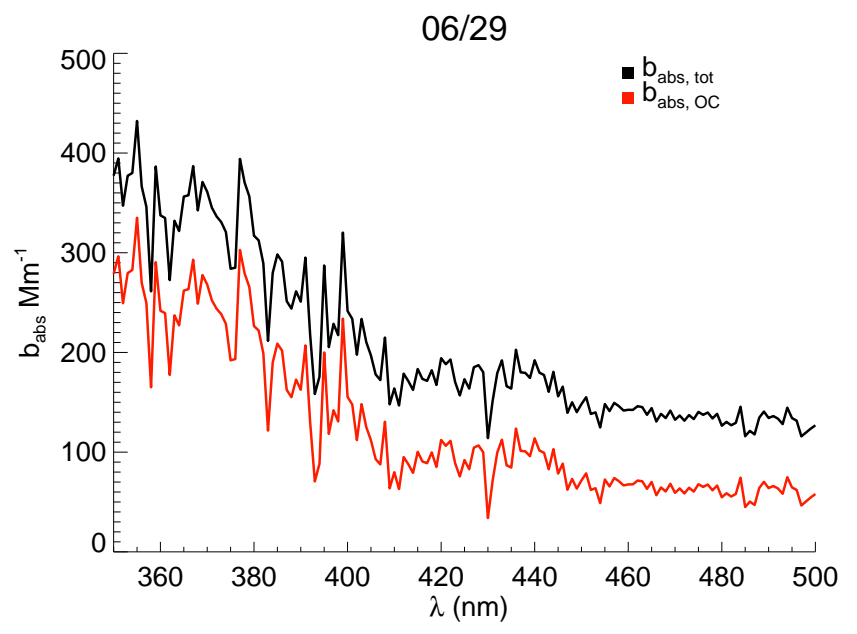

Fig. 7. Spectral $b_{\mathrm{abs}, \mathrm{OC}, \lambda}$ calculated from $b_{\mathrm{abs}, \lambda}$ using methods outlined in Arola et al. (2011) for 29 June.

Table 3. Contributions of OA to total, UV (350-399 nm), and visible $(400-500 \mathrm{~nm})$ retrieved absorption and for total, $470 \mathrm{~nm}$, and $532 \mathrm{~nm}$ PSAP absorption for 17 April and 29 June.

\begin{tabular}{llrr}
\hline & & 17 April & 29 June \\
\hline \multirow{2}{*}{ Retrieval } & Total & $57.7 \%$ & $56.2 \%$ \\
& UV $(350-399 \mathrm{~nm})$ & $80.1 \%$ & $69.2 \%$ \\
& Visible $(400-500 \mathrm{~nm})$ & $45.3 \%$ & $49.8 \%$ \\
\hline \multirow{2}{*}{ PSAP } & Total & $13.1 \%$ & $11.8 \%$ \\
& $470 \mathrm{~nm}$ & $17.5 \%$ & $13.8 \%$ \\
& $532 \mathrm{~nm}$ & $8.6 \%$ & $9.7 \%$ \\
\hline
\end{tabular}

17 April, suggesting the OA in the April plume has a greater spectral dependence of absorption.

Enhanced spectral absorption on 17 April may be explained by changes to the OA in biomass burning plumes as they age, and/or possibly by differences in the original OA emissions. The oxidation of biomass burning primary organic aerosol (POA) may result in the formation of compounds with stronger spectral absorption signatures than the biomass burning POA emitted at the source, as has been observed in previous studies (Decesari et al., 2002; Marley et al., 2009). Additionally, secondary organic aerosol (SOA) generated in several laboratory experiments via both the light (photochemical) and dark (e.g., reaction with $\mathrm{O}_{3}$ ) oxidation of gas-phase organics exhibited spectral absorption (Noziere et al., 2007; Bones et al., 2010; Zhong and Jang, 2011). Significant variability in SOA formation has been observed in biomass burning plumes, with some studies indicating substantial net SOA production and others showing none, but substantial OA aging has been observed in all studies (Grieshop et al., 2009b; Cubison et al., 2011; Hecobian et al., 2011; Hennigan et al., 2011; Jolleys et al., 2012). 
Table 4. Mean in-plume oxidation state values $\left(\mathrm{OS}_{\mathrm{C}}\right), \mathrm{OA} / \mathrm{BC}$, and AMS O/C ratios for 17 April and 29 June.

\begin{tabular}{lrr}
\hline & 17 April & 29 June \\
\hline OSc & 0.16 & -0.32 \\
OA/BC & 15.9 & 10.6 \\
O/C & 0.93 & 0.68 \\
\hline
\end{tabular}

Both the oxidation of biomass burning POA and the formation of biomass burning SOA would result in organic aerosol that was more oxidized than the emitted POA. Changes to biomass burning OA during aging have previously been studied by analyzing changes in ratios of key mass-to-charges $(\mathrm{m} / \mathrm{z})$ to total OA measured by the AMS (Grieshop et al., 2009a; Hawkins and Russell, 2010; Cubison et al., 2011; Hennigan et al., 2011). Recently, Kroll et al. (2011) proposed a parameter they called the "carbon oxidation state" $\left(\mathrm{OS}_{\mathrm{C}}\right)$ as a new method for quantifying the degree of aerosol oxidation using AMS data. $\mathrm{OS}_{C}$ is the average of all carbon atom oxidation states in the organic compound and can be estimated using the equation (Kroll et al., 2011)

$\mathrm{OS}_{\mathrm{C}}=2 \mathrm{O} / \mathrm{C}-\mathrm{H} / \mathrm{C}$

where $\mathrm{O} / \mathrm{C}$ is the elemental oxygen-to-carbon ratio and $\mathrm{H} / \mathrm{C}$ is the elemental hydrogen-to-carbon ratio, e.g. calculated from AMS data following Aiken et al. (2008). Unlike ratios of AMS fragments, the $\mathrm{OS}_{\mathrm{C}}$ is a fundamental parameter which can be derived with multiple methods and has a clear chemical interpretation. Typical values for atmospheric aerosol range from -2 to +1 , with more positive values indicating greater oxidation (Kroll et al., 2011).

Average $\mathrm{OS}_{\mathrm{C}}$ values calculated using Eq. (5) for each biomass burning plume were 0.16 and -0.32 for 17 April and 29 June, respectively (Table 4). The difference between the plume $\mathrm{OS}_{\mathrm{C}}$ values are primarily explained by differences in $\mathrm{O} / \mathrm{C}$ for each plume. While both plumes exhibit similar $\mathrm{H} / \mathrm{C}$ ratios (1.71 for 17 April and 1.69 for 29 June), the 17 April OA had a notably higher O/C (0.93) than 29 June (0.68). A higher $\mathrm{O} / \mathrm{C}$ ratio together with a higher $\mathrm{OS}_{\mathrm{C}}$ determined for the 17 April plume, suggest the 17 April OA is more oxidized than the 29 June OA. During ARCTAS, Hecobian et al. (2011) and Cubison et al. (2011) found little evidence for net SOA formation in the Canadian biomass burning plumes encountered by the DC-8, although some SOA formation may have been compensated by POA evaporation. The effect of SOA formation during transport of the Siberian plume is unconstrained by the ARCTAS data, but by analogy with the Canadian plumes it is likely to have been minor. Thus, the greater $\mathrm{OS}_{\mathrm{C}}$ in the 17 April plume is likely due to the oxidation of POA, either heterogeneously, or via evaporation-oxidation-recondensation. This is consistent with Marley et al. (2009) who found increases in the AAE with age without corresponding SOA formation.
As discussed in Sect. 3, UV SSA values are nearly identical for the two cases while visible SSA is higher for the aged 17 April plume. A similar "brightening" at visible wavelengths with age was observed in field studies of biomass burning aerosol (Abel et al., 2003; Adler et al., 2011). Thus, the increase in AAE with plume age observed here is largely due to the decrease in absorption at visible wavelengths with time. These findings may suggest that the oxidation of biomass burning OA primarily influences aerosol optical properties in the visible. This may, in part, be related to observed increases in particle size (and thus increased scattering at visible wavelengths) with age due to coagulation, water uptake, and condensation of gases (e.g., Grieshop et al., 2009a; Adler et al., 2011; Kondo et al., 2011), however changes to OA chemistry on a molecular level may also play a role. The similar UV SSA values between the aged 17 April plume and the fresh 29 June plume suggests similar amounts of UV absorption due to aerosols can be expected in fresh and aged plumes. This may have significant photochemical implications as it suggests reductions in photolysis rates in and below plumes (surface) due to aerosol UV absorption do not change with plume age. However, based on this work, this hypothesis would likely only apply to aged biomass burning POA; plumes that also include substantial SOA formation may result in enhanced UV absorption with plume age as OA with stronger UV-absorption signatures can be formed (Noziere et al., 2007; Bones et al., 2010; Zhong and Jang, 2011).

The observed relationship between $\mathrm{AAE}$ and $\mathrm{OS}_{\mathrm{C}}$ for the two cases may also be relevant for the remote sensing community. Previous studies have shown aerosol chemical composition may be retrievable from remote sensing platforms due to distinct differences in the AAE between aerosol plumes dominated by different aerosol types (Bergstrom et al., 2007; Russell et al., 2010). Our findings expand upon this to include OA oxidation as a possible retrievable parameter. This would mean that AAE retrievals may provide valuable information on plume age as well as SOA formation in addition to aerosol chemical composition. Our results may therefore suggest the AAE can be used to generate a novel remote sensing aerosol oxidation product, though more work is needed to confirm any possible relationship between AAE and OA oxidation.

\section{Summary and future work}

In-plume, mean aerosol spectral (350-550 nm) SSA was determined for an aged (17 April) and a fresh (29 June) biomass burning plume using actinic flux measured aboard the NASA DC-8 during the ARCTAS mission in 2008. Using methods outlined in Russell et al. (2010), AAE (350-500 nm) was calculated from retrieved SSA values and showed enhanced absorption, primarily due to $\mathrm{OA}$, in both plumes. Differences in AAE values calculated for absorption due to OA suggested stronger spectral absorption for OA in the 17 April plume 
than the 29 June plume, possibly due to a greater degree of oxidation of the 17 April OA.

The changes in the AAE with OA oxidation observed here have important implications for both the photochemical modeling and the remote sensing communities. However, due to the limited number of cases explored here, it is unclear whether this relationship holds more generally for aging biomass burning plumes in the atmosphere. Future work should aim to examine changes in aerosol spectral absorption with the oxidation of POA as well as with SOA formation. Special attention should be given to changes in aerosol optical properties with age at photochemically-relevant UV wavelengths in order to improve in-plume as well as surface photochemical modeling. Additionally, differences in AAE due to aerosol oxidation should be compared to differences in AAE due to aerosol type (i.e., dust versus biomass burning) to determine if the AAE-OA oxidation relationship is distinguishable from other composition-driven differences in the AAE.

While trends in retrieved SSA and AAE generally agree well with trends in in-situ ARCTAS data and literature results, some notable offsets exist in the magnitude of these parameters. This highlights the difficulty of using actinic flux in aerosol optical properties retrievals. Many retrievals to date have relied on irradiance data (e.g., Petters et al., 2003; Krotkov et al., 2005b; Corr et al., 2009; Buchard et al., 2011) which are much more sensitive to changes in the radiation field due to clouds, aerosol, surface albedo, and gases. To assess errors associated with actinic flux-based retrievals, results from such retrievals should be compared to those performed using co-located irradiance data. As actinic flux is typically used to determine photolysis rate coefficients, the ability to use it in aerosol retrievals would allow for the direct determination of aerosol impacts on photochemistry. Thus evaluating actinic flux retrieval performance will prove beneficial to the photochemical modeling community.

Acknowledgements. Chelsea A. Corr and Jack E. Dibb were supported for this work by NASA grant NNX08AH69G. Michael J. Cubison and Jose L. Jimenez thank NASA NNX08AD39G and NNX12AC03G for support. We thank Eddie Winstead for his assistance with the in-situ aerosol measurements. The acetonitrile measurements were supported by the Austrian Research Promotion Agency (FFG-ALR) and the Tiroler Zukunftstiftung, and were carried out with the help of T. Mikoviny, M Graus, A. Hansel and T. D. Maerk. We thank Yutaka Kondo and the University of Tokyo for the use of their black carbon measurements taken during ARCTAS. We also thank Ron Cohen and the University of California, Berkley for the use of their $\mathrm{NO}_{2}$ measurements and Andrew Weinheimer and the National Center for Atmospheric Research for their $\mathrm{O}_{3}$ measurements. Thanks also to Sasha Madronich for his assistance with the TUV 5.0 model in the initial stage of this work.

Edited by: Y. Balkanski

\section{References}

Abel, S. J., Haywood, J. M., Highwood, E. J., Li, J., and Buseck, P. R.: Evolution of biomass burning aerosol properties from an agricultural fire in southern Africa, Geophys. Res. Lett., 30, 1783, doi:10.1029/2003GL017342, 2003.

Adler, G., Flores, J. M., Abo Riziq, A., Borrmann, S., and Rudich, Y.: Chemical, physical, and optical evolution of biomass burning aerosols: a case study, Atmos. Chem. Phys., 11, 1491-1503, doi:10.5194/acp-11-1491-2011, 2011.

Aiken, A. C., DeCarlo, P. F., Kroll, J. H., Worsnop, D. R., Huffman, J. A., Docherty, K. S., Ulbrich, I. M., Mohr, C., Kimmel, J. R., Zhang, Q., Trimborn, A., Northway, M., Ziemann, P. J., Canagaratna, M. R., Onasch, T. B., Alfarra, M. R., Prevot, A. S. H., Dommen, J., Duplissy, J., Metzger, A., Baltensperger, U., and Jimenez, J. L.: O/C and OM/OC ratios of primary, secondary, and ambient organic aerosols with high resolution time-of-flight aerosol mass spectrometry, Environ. Sci. Technol., 42, 44784485, 2008.

Alados-Arboledas, L., Muller, D., Guerrero-Rascado, J. L., NavasGuzman, F., Perez-Ramirez, D., and Olmo, F. J., Optical and microphysical properties of fresh biomass burning aerosol retrieved by Raman lidar and star- and sun-photometry, Geophs. Res. Lett., 38, L01807, doi:10.1029/2010GL045999, 2011.

Anderson, T. L. and Ogren, J. A.: Determining aerosol radiative properties using the TSI 3563 integrating Nephelometer, Aerosol Sci. Tech., 29, 57-69, 1998.

Arola, A., Schuster, G., Myhre, G., Kazadzis, S., Dey, S., and Tripathi, S. N.: Inferring absorbing organic carbon content from AERONET data, Atmos. Chem. Phys., 11, 215-225, doi:10.5194/acp-11-215-2011, 2011.

Barnard, J. C., Volkamer, R., and Kassianov, E. I.: Estimation of the mass absorption cross section of the organic carbon component of aerosols in the Mexico City Metropolitan Area, Atmos. Chem. Phys., 8, 6665-6679, doi:10.5194/acp-8-6665-2008, 2008.

Bergstrom, R. W., Pilewskie, P., Schmid, B., and Russell, P. B.: Estimates of the spectral single scattering albedo and aerosol radiative effects during SAFARI 2000, J. Geophys. Res., 108, 8474, doi:10.1029/2002JD002435, 2003.

Bergstrom, R. W., Pilewskie, P., Russell, P. B., Redemann, J., Bond, T. C., Quinn, P. K., and Sierau, B.: Spectral absorption properties of atmospheric aerosols, Atmos. Chem. Phys., 7, 5937-5943, doi:10.5194/acp-7-5937-2007, 2007.

Betts, A. K. and Ball, J. H.: Albedo over the boreal forest, J. Geophys. Res., 102, 28901-28909, 1997.

Bond, T. C., Streets, D. G., Yarber, K. F., Nelson, S. M. Woo, J. M., and Klimont, Z.: A technology-based global inventory of black and organic carbon emissions from combustion, J. Geophys. Res., 109, D14203, doi:10.1029/2003JD003697, 2004.

Bones, D. L., Henricksen, D. K., Mang, S. A., Gonsior, M., Bateman, A. P., Nguyen, T. B., Cooper, W. J., and Nizkorodov, S. A.: Appearance of strong absorbers and fluorophores in limonene$\mathrm{O}_{3}$ secondary organic aerosol due to $\mathrm{NH} 4+-$ mediated chemical aging over long time scales, J. Geophys. Res., 115, D05203, doi:10.1029/2009JD012864, 2010.

Buchard, V., Brogniez, C., Auriol, F., and Bonnel, B.: Aerosol single scattering albedo retrieved from ground-based measurements in the UV and visible region, Atmos. Meas. Tech., 4, 1-7, doi:10.5194/amt-4-1-2011, 2011. 
Canagaratna, M. R., Jayne, J. T., Jimenez, J. L., Allan, J. D., Alfarra, M. R., Zhang, Q., Onasch, T. B., Drewnick, F., Coe, H., Middlebrook, A., Delia, A., Williams, L. R., Trimborn, A. M., Northway, M. J., DeCarlo, P. F., Kolb, C. E., Davidovits, P., and Worsnop, D. R.: Chemical and microphysical characterization of ambient aerosols with the Aerodyne Aerosol Mass Spectrometer, Mass Spectrom. Rev., 26, 185-222, 2007.

Chen, Y. and Bond, T. C.: Light absorption by organic carbon from wood combustion, Atmos. Chem. Phys., 10, 1773-1787, doi:10.5194/acp-10-1773-2010, 2010.

Chen, L.-W. A., Moosmuller, H., Arnott, W. P., Chow, J. C., and Watson, J. G.: Particle emissions from laboratory combustion of wildland fuels; In situ optical and mass measurements, Geophys. Res. Lett., 33, L04803, doi:10.1029/2005GL024838, 2006.

Clarke, A., McNaughton, C., Kapustin, V., Shinozuka, Y., Howell, S., Dibb, J., Zhou, J., Anderson, B., Brekhovskikh, V., Turner, H., and Pinkerton, M.: Biomass burning and pollution aerosol over North America: Organic components and their influence of spectral optical properties and humidification response, J. Geophys. Res., 112, D12S18, doi:10.1029/2006Jd007777, 2007.

Corr, C. A., Krotkov, N., Madronich, S., Slusser, J. R., Holben, B., Gao, W., Flynn, J., Lefer, B., and Kreidenweis, S. M.: Retrieval of aerosol single scattering albedo at ultraviolet wavelengths at the T1 site during MILAGRO, Atmos. Chem. Phys., 9, 58135827, doi:10.5194/acp-9-5813-2009, 2009.

Cubison, M. J., Ortega, A. M., Hayes, P. L., Farmer, D. K., Day, D., Lechner, M. J., Brune, W. H., Apel, E., Diskin, G. S., Fisher, J. A., Fuelberg, H. E., Hecobian, A., Knapp, D. J., Mikoviny, T., Riemer, D., Sachse, G. W., Sessions, W., Weber, R. J., Weinheimer, A. J., Wisthaler, A., and Jimenez, J. L.: Effects of aging on organic aerosol from open biomass burning smoke in aircraft and laboratory studies, Atmos. Chem. Phys., 11, 12049-12064, doi:10.5194/acp-11-12049-2011, 2011.

Decesari, S., Facchini, M. C., Matta, E., Mireca, M., Fuzzi, S., Chughtai, A. R., and Smith, D. M.: Water soluble organic compounds form by oxidation of soot, Atmos. Environ., 36, 18271832, 2002.

Dickerson, R., Kondragunta, S., Stenchikov, G., Civerolo, K., Doddridge, B., and Holben, B.: The impact of aerosol on solar UV radiation and photochemical smog, Science, 278, 827-830, 1997.

Eck, T. F., Holben, B. N., Reid, J. S., Dubovik, O., Smirnov, A., O'Neill, N. T., Slutsker, I., and Kinne, S.: Wavelength dependence of the optical depth of biomass burning, urban, and desert dust aerosols, J. Geophys. Res., 104, 31333-31349, 1999.

Eck, T. F., Holben, B. N., Reid, J. S., O’Neill, N. T., Schafer, J. S., Dubovik, O., Smirnov, A., Yamasoe, M. A., and Artaxo, P.: High aerosol optical depth biomass burning events: A comparison of optical properties for different source regions, Geophys. Res. Lett., 30, 2035, doi:10.1029/2003GL017861, 2003.

Eck, T. F., Holben, B. N., Reid, J. S., Sinyuk, A., Hyer, E. J., O'Neill, N. T., Shaw, G. E., Vande Castle, J. R., Chapin, F. S., Dubovik, O., Smirnov, A., Vermote, E., Schafer, J. S., Giles, D., Slutsker, I., Sorokine, M., and Newcomb, W. W.: Optical properties of boreal region biomass burning aerosols in Central Alaska and seasonal variation of aerosol optical depth at an Arctic coastal site, J. Geophys. Res., 114, D11201, doi:10.1029/2008JD010870, 2009.

Elterman, L., Wexler, R., and Chang, D. T.: Features of tropospheric and stratospheric dust, Appl. Optics, 8, 893-903, 1969.
Favez, O., Alfaro, S. C., Sciare, J., Cachier, H., and Abdelwahab, M. M.: Ambient measurements of light-absorption by agricultural waste burning organic aerosols, J. Aero. Sci., 40, 613-620, 2009.

Flynn, J., Lefer, B., Rappengluck, B., Leuchner, M., Perna, R., Dibb, J., Ziemba, L., Anderson, C., Stutz, J., Brune, W., Ren, X., Mao, J., Luke, W., Olson, J., Chen, G., and Crawford, J.: Impact of clouds and aerosols on ozone production in Southeast Texas, Atmos. Environ., 44, 4126-4133, 2010.

Forster, P., Ramaswamy, V., Artaxo, P., Bernsten, T., Betts, R., Fahey, D. W., Haywood, J., Lean, J., Lowe, D. C., Myhre, G., Nganga, J., Prinn, R., Raga, G., Schulz, M., and Van Dorland, R.: Changes in Atmospheric Constituents and in Radiative Forcing, In: Climate Change, 2007: The Physical Science Basis, Contribution of Working Group I to the Fourth Assessment Report of the Intergovernmental Panel on Climate Change., edited by: Solomon, S., Qin, D., Manning, M., Chen, Z., Marquis, M., Averyt, K. B., Tignor, M. and Miller, H. L., Cambridge University Press, Cambridge, United Kingdom and New York, NY, USA, 129-234, 2007

Grieshop, A. P., Donahue, N. M., and Robinson, A. L.: Laboratory investigation of photochemical oxidation of organic aerosol from wood fires 2: analysis of aerosol mass spectrometer data, Atmos. Chem. Phys., 9, 2227-2240, doi:10.5194/acp-9-2227-2009, 2009a.

Grieshop, A. P., Logue, J. M., Donahue, N. M., and Robinson, A. L.: Laboratory investigation of photochemical oxidation of organic aerosol from wood fires 1: measurement and simulation of organic aerosol evolution, Atmos. Chem. Phys., 9, 1263-1277, doi:10.5194/acp-9-1263-2009, 2009b.

Hawkins, L. N. and Russell L. M.: Oxidation of ketone groups in transported biomass burning aerosol from the 2008 Northern California Lightning Series fires, Atmos. Environ., 44, 41424154, 2010.

Haywood, J. M., Osborne, S. R., Francis, P. N., Keil, A., Formenti, P., Andreae, M. O., and Kaye, P. H.: The mean physical optical properties for regional haze dominated by biomass burning aerosol measured from the C-130 aircraft during SAFARI 2000, J. Geophys. Res., 108, 8473, doi:10.1029/2002JD002226, 2003.

He, S. and Carmichael, G. R.: Sensitivity of photolysis rates and ozone production in the troposphere to aerosol properties, J. Geophys. Res. 104, 26307-26324, 1999.

Hecobian, A., Zhang, X., Zheng, M., Frank, N., Edgerton, E. S., and Weber, R. J.: Water-Soluble Organic Aerosol material and the light-absorption characteristics of aqueous extracts measured over the Southeastern United States, Atmos. Chem. Phys., 10, 5965-5977, doi:10.5194/acp-10-5965-2010, 2010.

Hecobian, A., Liu, Z., Hennigan, C. J., Huey, L. G., Jimenez, J. L., Cubison, M. J., Vay, S., Diskin, G. S., Sachse, G. W., Wisthaler, A., Mikoviny, T., Weinheimer, A. J., Liao, J., Knapp, D. J., Wennberg, P. O., Kürten, A., Crounse, J. D., Clair, J. St., Wang, Y., and Weber, R. J.: Comparison of chemical characteristics of 495 biomass burning plumes intercepted by the NASA DC-8 aircraft during the ARCTAS/CARB-2008 field campaign, Atmos. Chem. Phys., 11, 13325-13337, doi:10.5194/acp-1113325-2011, 2011.

Hennigan, C. J., Miracolo, M. A., Engelhart, G. J., May, A. A., Presto, A. A., Lee, T., Sullivan, A. P., McMeeking, G. R., Coe, H., Wold, C. E., Hao, W.-M., Gilman, J. B., Kuster, W. C., de Gouw, J., Schichtel, B. A., J. L. Collett Jr., Kreidenweis, S. M., 
and Robinson, A. L.: Chemical and physical transformations of organic aerosol from the photo-oxidation of open biomass burning emissions in an environmental chamber, Atmos. Chem. Phys., 11, 7669-7686, doi:10.5194/acp-11-7669-2011, 2011.

Hoffer, A., Gelencsér, A., Guyon, P., Kiss, G., Schmid, O., Frank, G. P., Artaxo, P., and Andreae, M. O.: Optical properties of humic-like substances (HULIS) in biomass-burning aerosols, Atmos. Chem. Phys., 6, 3563-3570, doi:10.5194/acp-6-3563-2006, 2006.

Hornbrook, R. S., Blake, D. R., Diskin, G. S., Fried, A., Fuelberg, H. E., Meinardi, S., Mikoviny, T., Richter, D., Sachse, G. W., Vay, S. A., Walega, J., Weibring, P., Weinheimer, A. J., Wiedinmyer, C., Wisthaler, A., Hills, A., Riemer, D. D., and Apel, E. C.: Observations of nonmethane organic compounds during ARCTAS - Part 1: Biomass burning emissions and plume enhancements, Atmos. Chem. Phys., 11, 11103-11130, doi:10.5194/acp11-11103-2011, 2011.

Jacob, D. J., Crawford, J. H., Maring, H., Clarke, A. D., Dibb, J. E., Emmons, L. K., Ferrare, R. A., Hostetler, C. A., Russell, P. B., Singh, H. B., Thompson, A. M., Shaw, G. E., McCauley, E., Pederson, J. R., and Fisher, J. A.: The Arctic Research of the Composition of the Troposphere from Aircraft and Satellites (ARCTAS) mission: design, execution, and first results, Atmos. Chem. Phys., 10, 5191-5212, doi:10.5194/acp-10-5191-2010, 2010.

Johnson, B. T., Osborne, S. R., Haywood, J. M., and Harrison, M. A. J.: Aircraft measurements of biomass burning aerosol over West Africa during DABEX, J. Geophys. Res., 113, D00C06, doi:10.1029/2007JD009451, 2008.

Jolleys, M. D., Coe, H., McFiggans, G., Capes, G., Allan, J. D., Crosier, J., Williams, P. I., Allen, G., Bower, K. N., and Jimenez, J. L.: Characterisation of regional ambient biomass burning organic aerosol mixing ratios and their evolution with aging, Environ. Sci. Technol., in review, 2012.

Kirchstetter, T. W., Novakov, T., and Hobbs, P. V.: Evidence that the spectral dependence of light absorption by aerosols is affected by organic carbon, J. Geophys. Res., 109, D21208, doi:10.1029/2004JD004999, 2004.

Kondo, Y., Matsui, H., Moteki, N., Sahu, L., Takegawa, N., Kajino, M., Zhao, Y., Cubison, M. J., Jimenez, J. L., Vay, S., Diskin, G. S., Anderson, B., Wisthaler, A., Mikoviny, T., Fuelberg, H. E., Blake, D. R., Huey, G., Weinheimer, A. J, Knapp, D. J., and Brune, W. H.: Emissions of black carbon, organic, and inorganic aerosols from biomass burning in North America and Asia in 2008, J. Geophys. Res., 116, D08204, doi:10.1029/2010JD015152, 2011.

Kroll, J. H., Donahue, N. M., Jimenez, J. L., Kessler, S. H., Canagaratna, M. R., Wilson, K. R., Altieri, K. E., Mazzoleni, L. R., Wozniak, A. S., Bluhm, H., Mysak, E. R., Smith, J. D., Kolb, C. E., and Worsnop, D. R.: Carbon oxidation state as a metric for describing the chemistry of atmospheric organic aerosol, Nature Chemistry, 3, 133-139, 2011.

Krotkov, N., Bhartia, P. K., Herman, J., Slusser, J., Labow, G., Scott, G., Janson, G., Eck, T. F., and Holben, B.: Aerosol ultraviolet absorption experiment (2002 to 2004), part 1: ultraviolet multifilter rotating shadowband radiometer calibration and intercomparison with CIMEL sunphotometers, Opt. Eng., 44, 041004, doi:10.1117/1.1886818, 2005a.

Krotkov, N., Bhartia, P. K., Herman, J., Slusser, J., Scott, G., Labow, G., Vasilkov, A. P., Eck, T. F., Dubovik, O., and Holben, B. N.:
Aerosol ultraviolet absorption experiment (2002 to 2004), part 2: absorption optical thickness, refractive index, and single scattering albedo, Opt. Eng., 44, 041005, doi:10.1117/1.1886819, 2005b.

Lack, D. A., Cappa, C. D., Covert, D. S., Baynard, T., Massoli, P., Sierau, B., Bates, T. S., Quinn, P. K., Lovejoy, E. R., and Ravishankara, A. R.: Bias in filter-based aerosol light absorption measurements due to organic aerosol loading: Evidence from ambient measurements, Aerosol Sci. Tech., 42, 1033-1041, 2008.

Lefer, B. L., Shetter, R. E., Hall, S. R., Crawford, J. H., and Olson, J. R.: Impact of clouds and aerosols on photolysis frequencies and photochemistry during TRACE-P: 1 , Analysis using radiative transfer and photochemical box models, J. Geophys. Res., 108, 8821, doi:10.1029/2002JD003171, 2003.

Lewis, K., Arnott, W. P., Moosmuller, H., and Wold, C. E.: Strong spectral variation of biomass smoke light absorption and single scattering albedo observed with a novel dual-wavelength photoacoustic instrument, J. Geophys. Res., 113, D16203, doi:10.1029/2007JD009699, 2008.

Li, G., Bei, N., Tie, X., and Molina, L. T.: Aerosol effects on the photochemistry in Mexico City during MCMA2006/MILAGRO campaign, Atmos. Chem. Phys., 11, 51695182, doi:10.5194/acp-11-5169-2011, 2011.

Lopez, M. L., Palancar, G. G., and Toselli, B. M.: Effect of different types of clouds on surface UV-B and total solar irradiance at southern mid-latitudes: $\mathrm{CMF}$ determinations at Cordoba, $\mathrm{Ar}-$ gentina, Atmos. Environ., 43, 3130-3136, 2009.

Lyapustin, A., Gatebe, C. K., Kahn, R., Brandt, R., Redemann, J., Russell, P., King, M. D., Pedersen, C. A., Gerland, S., Poudyal, R., Marshak, A., Wang, Y., Schaaf, C., Hall, D., and Kokhanovsky, A.: Analysis of snow bidirectional reflectance from ARCTAS Spring-2008 Campaign, Atmos. Chem. Phys., 10, 4359-4375, doi:10.5194/acp-10-4359-2010, 2010.

Mack, L. A., Levin, E. J. T., Kreidenweis, S. M., Obrist, D., Moosmüller, H., Lewis, K. A., Arnott, W. P., McMeeking, G. R., Sullivan, A. P., Wold, C. E., Hao, W.-M., Collett Jr., J. L., and Malm, W. C.: Optical closure experiments for biomass smoke aerosols, Atmos. Chem. Phys., 10, 9017-9026, doi:10.5194/acp10-9017-2010, 2010.

Madronich, S. and Flocke, S.: The role of solar radiation in atmospheric chemistry, in: Handbook of Environmental Chemistry, edited by: Boule, P., Springer-Verlag, Heidelberg, Germany, 126, 1998.

Marley, N. A., Gaffney, J. S., Tackett, M., Sturchio, N. C., Heraty, L., Martinez, N., Hardy, K. D., Marchany-Rivera, A., Guilderson, T., MacMillan, A., and Steelman, K.: The impact of biogenic carbon sources on aerosol absorption in Mexico City, Atmos. Chem. Phys., 9, 1537-1549, doi:10.5194/acp-9-1537-2009, 2009.

McMeeking, G. R., Kreidenweis, S. M., Lunden, M., Carrillo, J., Carrico, C. M., Lee, T., Herckes, P., Engling, G., Day, D. E., Hand, J., Brown, N., Malm, W. C., and Collett, J. L.: Smokeimpacted regional haze in California during the summer of 2002, Agr. Forest Meteorol., 137, 25-42, 2006.

McNaughton, C. S., Clarke, A. D., Freitag, S., Kapustin, V. N., Kondo, Y., Moteki, N., Sahu, L., Takegawa, N., Schwarz, J. P., Spackman, J. R., Watts, L., Diskin, G., Podolske, J., Holloway, J. S., Wisthaler, A., Mikoviny, T., de Gouw, J., Warneke, C., Jimenez, J., Cubison, M., Howell, S. G., Middlebrook, A., Bahreini, R., Anderson, B. E., Winstead, E., Thornhill, K. L., 
Lack, D., Cozic, J., and Brock, C. A.: Absorbing aerosol in the troposphere of the Western Arctic during the 2008 ARCTAS/ARCPAC airborne field campaigns, Atmos. Chem. Phys., 11, 7561-7582, doi:10.5194/acp-11-7561-2011, 2011.

Moody, E. G, King, M.D., Schaaf, C. B., Hall, D. K., and Platnick, S.: Northern hemisphere five-year average (2000-2004) spectral albedo of surfaces in the presence of snow: Statistics computed from Terra MODIS land products, Remote Sens. Environ., 111, 337-345, 2007.

Noziere, B., Dziedzic, P., and Cordova, A.: Formation of secondary light-absorbing "fulvic-like" oligomers: A common process in aqueous and ionic atmospheric particles?, Geophys. Res. Lett., 34, L21812, doi:10.1029/2007GL031300, 2007.

Osborne, S. R. and Haywood, J. M.: Aircraft observations of the microphysical and optical properties of major aerosol species, Atmos. Res., 73, 172-201, 2005.

Petters, J. L., Saxena, V. K., Slusser, J. R., Wenny, B. N., and Madronich, S.: Aerosol single scattering albedo retrieved from measurements of surface UV voltage and a radiative transfer model, J. Geophys. Res., 108, 4288, doi:10.1029/2002JD002360, 2003.

Reid, J. S. and Hobbs, P. V.: Physical and optical properties of young smoke from individual biomass fires in Brazil, J. Geophys. Res., 103, 32013-32030, 1998.

Russell, P. B., Bergstrom, R. W., Shinozuka, Y., Clarke, A. D., DeCarlo, P. F., Jimenez, J. L., Livingston, J. M., Redemann, J., Dubovik, O., and Strawa, A.: Absorption Angstrom Exponent in AERONET and related data as an indicator of aerosol composition, Atmos. Chem. Phys., 10, 1155-1169, doi:10.5194/acp-101155-2010, 2010.

Sandradewi, J., Prevot, A. S. H., Weingartner, E., Schmidhauser, R., Gysel, M., and Baltensperger, U.: A study of wood burning and traffic aerosols in an Alpine valley using a multi-wavelength Aethalometer, Atmos. Environ., 42, 101-112, 2008.
Shetter, R. E. and Muller, M.: Photolysis frequency measurements using actinic flux spectroradiometery during the PEM-Tropics mission: Instrumentation descriptions and some results, J. Geophys. Res., 104, 5647-5661, 1999.

Shinozuka, Y., Clarke, A. D., Howell, S. G., Kapustin, V. N., McNaughton, C. S., Zhou, J., and Anderson, B. E.: Aircraft profiles of aerosol microphysics and optical properties over North America: Aerosol optical depth and its association with PM2.5 and water uptake, J. Geophys. Res., 112, D12S20, doi:10.1029/2006JD007918, 2007.

Tesche, M., Muller, D., Gross, S., Ansmann, A., Althanusen, D., Freudenthaler, V., Weinzierl, B., Veira, A., and Petzold, A.: Optical and microphysical properties of smoke over Cape Verde inferred from multiwavelength lidar measurements, Tellus B, 63B, 677-694, 2011.

Turetsky, M. R., Kane, E. S., Harden, J. W., Ottmar, R. D., Manies, K. L., Hoy, E., and Kasischke, E. S.: Recent acceleration of biomass burning and carbon losses in Alaskan forests and peatlands, Nat. Geosci., 4, 27-31, 2011.

Wendisch, M., Pilewskie, P., Jakel, E., Schmidt, S., Pommier, J., Howard, S., Jonsson, H. H., Guan, H., Schroder, M., and Mayer, B.: Airborne measurements of areal spectral surface albedo over different sea and land surfaces, J. Geophys. Res., 109, D08203, doi:10.1029/2003JD004392, 2004.

Yang, M., Howell, S. G., Zhuang, J., and Huebert, B. J.: Attribution of aerosol light absorption to black carbon, brown carbon, and dust in China - interpretations of atmospheric measurements during EAST-AIRE, Atmos. Chem. Phys., 9, 2035-2050, doi:10.5194/acp-9-2035-2009, 2009.

Zhong, M. and Jang, M.: Light absorption coefficient measurement of SOA using a UV-Visible spectrometer connected with an integrating sphere, Atmos. Environ., 45, 4263-4271, 2011. 